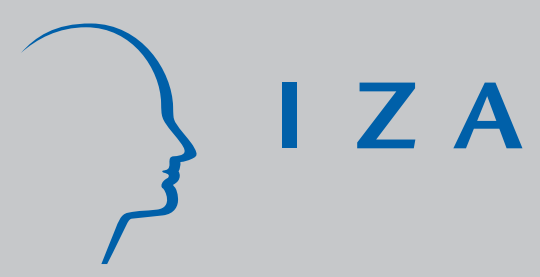

IZA DP No. 4148

A Comparison and Decomposition of Reform-Era Labor Force Participation Rates of China's Ethnic Minorities and Han Majority

Margaret Maurer-Fazio

J ames W. Hughes

Dandan Zhang

April 2009 


\title{
A Comparison and Decomposition of Reform-Era Labor Force Participation Rates of China's Ethnic Minorities and Han Majority
}

\author{
Margaret Maurer-Fazio \\ Bates College and IZA \\ James W. Hughes \\ Bates College \\ Dandan Zhang \\ Australian National University
}

Discussion Paper No. 4148

April 2009

IZA

P.O. Box 7240

53072 Bonn

Germany

Phone: +49-228-3894-0

Fax: +49-228-3894-180

E-mail: iza@iza.org

Any opinions expressed here are those of the author(s) and not those of IZA. Research published in this series may include views on policy, but the institute itself takes no institutional policy positions.

The Institute for the Study of Labor (IZA) in Bonn is a local and virtual international research center and a place of communication between science, politics and business. IZA is an independent nonprofit organization supported by Deutsche Post Foundation. The center is associated with the University of Bonn and offers a stimulating research environment through its international network, workshops and conferences, data service, project support, research visits and doctoral program. IZA engages in (i) original and internationally competitive research in all fields of labor economics, (ii) development of policy concepts, and (iii) dissemination of research results and concepts to the interested public.

IZA Discussion Papers often represent preliminary work and are circulated to encourage discussion. Citation of such a paper should account for its provisional character. A revised version may be available directly from the author. 


\begin{abstract}

\section{A Comparison and Decomposition of Reform-Era Labor Force} Participation Rates of China's Ethnic Minorities and Han Majority

This paper examines differences in China's ethnic majority and minority patterns of labor force participation and decomposes these differences into treatment and endowment effects using the technique developed by Borooah and lyer (2005). Population census data are used to estimate gender-separated urban labor force participation rates (Ifpr) using logit regressions which control for educational attainment, marital status, pre-school and schoolage children, household size, age, and measures of local economic conditions. We focus on six minority groups (Hui, Koreans, Manchu, Mongolians, Uygurs, and Zhuang) and the majority Han. We find sizable differences between the Ifpr of urban women of particular ethnic groups and the majority Han. Men's Ifpr are very high and exhibit little difference between Han and ethnic minorities. For almost all pair-wise comparisons between Han and minority women, we find that differences in coefficients account for more than $100 \%$ of the Han-ethnic difference in labor force participation. Differences in endowments often have substantial effects in reducing this positive Han margin in labor force participation. Roughly speaking, treatment of women's characteristics, whether in the market or socially, tend to increase the Han advantage in labor force participation. The levels of these characteristics on average tend to reduce this Han advantage.
\end{abstract}

JEL Classification: J1, J2, J7, O1, O5, P2

Keywords: China, ethnic minorities, labor force participation, economic reform, population censuses

Corresponding author:

Margaret Maurer-Fazio

276 Pettengill Hall

Bates College

4 Andrews Road

Lewiston, ME 04240

USA

E-mail: mmaurer@bates.edu 
“All nationalities in the People's Republic of China are equal.... Discrimination against and oppression of any nationality are prohibited...." (Article 4 of the Constitution of the People's Republic of China)

\section{Introduction}

This paper contributes to the scant literature on ethnicity in China's economic transition. In the late 1970s the Chinese leadership embarked on a program of economic reform which initiated a transition to a market economy. At the national level, the transition led to rapid and sustained income growth and welfare improvements. Less is known about how China's different ethnic groups have fared in the reform process. The aim of this paper is to fill part of the gap.

\section{China’s Ethnic Minorities}

According to China's 2000 population census, $8.5 \%$ of the Chinese population (106 million people) was classified as ethnic minority. When we use the terms ethnic minority, national minority or minority people here we are referring to the 55 national minorities that, with the Han majority, make up the 56 ethnic groups officially recognized by the Chinese central government. Chinese policies towards ethnic minorities stem in part from a legacy inherited from dynastic leaders, in part from an ethnic identification project built on Stalinist principles and implemented in the early years of the People's Republic, and in part from an array of adaptations to specific local situations. In the mid-1980s, government policy increased the benefits to minority identification ${ }^{1}$ and thus provided an incentive for change in ethnic identity. Consequently, when on the basis of fertility trends an increase of 10 million

\footnotetext{
${ }^{1}$ The government's preferential policies include an exemption from, or easing of, the restrictions of the government's family planning program, as well as preferential treatment in school admissions, hiring and promotion, the financing and taxation of businesses and the provision of infrastructure (Sautman, p.86). Whether and how these policies are implemented is an important issue.
} 
was expected, the actual number of people self- identifying as ethnic minorities in the 1990 census increased by 24 million. $^{2}$

Much of China's total land area (63.9 percent), particularly the politically sensitive border regions in northwestern, southwestern, and northeastern China, is designated as autonomous ethnic minority regions (State Ethnic Affairs Committee (SEAC) 2003: 545), and many of China’s minority people (75 percent) reside in these specially designated areas (Information Office of the State Council of the People's Republic of China 1999: 15). Published economic statistical data on China’s minority peoples is almost always presented by autonomous region rather than by ethnic group. ${ }^{3}$ This makes it difficult to shed light on questions about the economic wellbeing of China’s minority peoples since the Han often comprise a significant proportion of the population in autonomous regions. ${ }^{4}$

Overall economic indicators show a rising standard of living in ethnic minority regions. Colin Mackerras (2003: 56-76) examines numerous indicators of the standard of living in China’s minority areas, including measure of rural income, wages, healthcare provision, infrastructure development, and industrial development, concluding that since 1990 minorities have radically improved their standard of living. However, these improvements have not kept pace with developments in the

\footnotetext{
${ }^{2}$ The Manchu and Tujia populations increased particularly rapidly between the 1982 and 1990 censuses.

${ }^{3}$ See for example China's Yearbook of Ethnic Works (SEAC 2003), China's Ethnic Statistical Yearbook (State Ethnic Affairs Committee, Department of Economic Development, and National Bureau of Statistics of China, PRC Department of Integrated Statistics 2000), and the Statistical Yearbooks of China (National Bureau of Statistics of China 2005). Katherine Palmer Kaup (2000: 149) suggests that the income inequalities between ethnic groups are so pronounced that if published would become a very contentious issue.

${ }^{4}$ For example, in 2002, the minority population of the Inner Mongolian Autonomous Region constituted only 20.9 percent of its total population. Comparable figures for Guangxi Zhuang and the Ningxia Hui Autonomous Regions are 38.4 percent and 35.4 percent, respectively. Tibet and Xinjiang Uygur Autonomous Regions are notable exceptions, with the minority populations constituting 96.7 and 60.1 percent of their respective populations (NBS and SEAC 2003: 564, Tables 2-8).
} 
national economy. China's minorities dwell predominately in western China, a region that includes China's poorest provinces and lags far behind the eastern seaboard provinces in terms of income and economic development.

Socioeconomic treatises on China's ethnic groups (as opposed to autonomous regions) are rare. One notable exception is the work of Gustafsson and Li who make an important contribution to the economic literature about China's minority nationalities. They employ survey data gathered in 1988 and 1995 from 19 provinces, to assess the differences in rural income between the Han majority and ethnic minorities (grouped together). They find that the per capita income gap of 19.2\% in the earlier period grew to $35.9 \%$ in the latter period. When they decompose the income differential into differences due to endowments and treatment they find that the lion's share of the differential is due to differences in endowments and that minority incomes are lower than Han incomes largely due to location. They note that China's minorities are clustered in provinces with low per capital GDP and tend to dwell in mountainous areas and areas officially designated as poor.

Gustaffson and Ding build on this earlier work, employing survey data from 22 provinces gathered in 2002 to analyze differences between ethnic minority people (grouped together) and majority people in the levels of temporary and persistent poverty in rural China. They too argue that poverty in rural China has a very strong spatial dimension — that ethnic minorities have higher rates of both persistent and temporary poverty because minorities are concentrated in western China, home to most of China's poor. They find that the rates of poverty differ little between minorities and the majority in western China. They report that factors such as the education level of the household head, village mean income, and whether the village 
is located in a mountainous area are much more important than ethnicity in explaining poverty and that ethnic minority status has little independent effect.

Hannum and Xie, in another important contribution to this literature, focus on an array of particular minorities in a single province. They employ population census data to examine the effects of market reform on differences in occupational attainment of Xinjiang's (mainly Turkic) minorities in comparison to the Han. Hannum and Xie find that the ethnic gap in occupational attainment between the Han and the minorities widened between the 1982 and 1990 censuses. They attribute the rising gap to an increased gap in educational attainment between the Han and the minorities and a strengthening of the relationship between educational attainment and higher-status occupations.

Ding and Li analyze income inequality and differences in income determination for Hui and Han urban residents in Ningxia based on survey data gathered in 2007. They decompose differences in earnings into treatment and endowment effects and find that the treatment effects are more important than endowment effects in explaining the incomes differences between the Hui and Han. It is important to note, however, that the treatment effects do not necessarily favor the Han. Ding and Li report that returns to education are somewhat higher for the Han than the Hui, while the returns to experience are higher for the Hui than the Han. Similarly, party membership favors (has a bigger return for) the Hui while state ownership of the workplace favors the Han. Maurer-Fazio, Hughes, and Zhang (2007) analyze trends in the labor force participation of China's minorities between 1990 and 2000. They find that minorities were affected more adversely than Han by reductions in urban sector employment and exited the labor force more rapidly than Han. 
The papers of Gustafsson and Li and Hannum and Xie suggest that minorities have not fared well in China's transition - that both rural income and occupational attainment gaps between minorities and the Han have widened. The former paper argues that location rather than ethnicity is the causal factor in the widening rural income gap while the latter paper suggests that important ethnic differences in labor market outcomes remain even after carefully controlling for location. Similarly, Gustaffson and Ding argue that rural poverty is better explained by location rather than ethnicity while Ding and Li find ethnicity a significant factor in urban income determination.

This nascent but growing literature on ethnicity in China's transition has addressed rural and urban income, rural poverty, and occupational attainment and touched on urban labor force participation. We add to this literature by deepening the analysis of the labor force participation of a number of China's important ethnic groups. We expand on the earlier analysis of Maurer-Fazio, Hughes, and Zhang in several significant ways. First, we extend the time period from 1982 to 2000 and include a larger set of ethnic minorities. More importantly, we control for both demographic factors and local economic conditions. We are particularly interested in whether the differences in majority and minority economic labor force participation rates are mainly attributable to differences in ethnic groups' attributes or the treatment of those attributes.

\section{Research Strategy}

We utilize the method developed by Borooah and Iyer (2005) to decompose differences in labor force participation rates between the Han majority and a number of minorities into coefficient and attribute effects. The Borooah Iyer model extends 
the well-known Oaxaca-Blinder decomposition method to logit models and, importantly for our case, allows the inclusion of multiple groups. Our analysis is based on the data of the 1982, 1990, and 2000 population censuses of China which identify individuals' ethnic status and allow us to overcome some of the abovementioned data scarcity problems.

We focus our analysis on the labor force participation patterns of urban residents. ${ }^{5}$ We concentrate on six important minority groups and the Han majority. The limited number of urban ethnic minority residents in the census samples determined which groups we could include in our analysis. We’ve included every minority group with sufficient sample size to successfully run (with a consistent set of explanatory variables) the logits which underlie the Borooah Iyer method. We thus carry out pair wise comparisons of the differences in labor force participation between the Han and Hui, Koreans, Manchu, Mongolians, Uygurs, and Zhuang. ${ }^{6}$

We divide our samples by gender and separately analyze men’s and women’s labor force participation. Men’s labor force participation rates for both majority and minority men are extremely high in international perspective. Since there is very little difference by ethnicity between men's labor force participation rates, we have relegated the men's analysis to Appendix Tables 1 and 2. In the following sections of this paper, we focus our analysis and discussion on the differences in women's labor force participation.

\footnotetext{
${ }^{5}$ Chinese population census questionnaires do not include any questions about income.

${ }^{6}$ The Zhuang have the largest population amongst China's minorities. They reside in the southwestern China. The Mongolian and Uygur populations are geographically concentrated in politically sensitive areas in northern and northwestern China. The Hui and Uygurs are Muslim minorities. The Hui are broadly dispersed through China. The high education levels and older age structure of the Koreans make them quite distinct. Both the Koreans and Manchu reside in northeastern China.
} 
In the next section we discuss our theoretical predictions about how the reforms might influence labor force participation rates. The following section describes the data used in this project. We then report estimates of urban labor force participation rates using logit regressions on the 1982, 1990, and 2000 data. These regressions controls for ethnic group, educational attainment, marital status, household composition, age, and local economic conditions and allow us to determine whether the participation rates of particular ethnic groups differ from that of the Han majority and whether there are any discernible trends in such differences over time. We then employ the Borooah Iyer technique to decompose the differences in labor force participation into treatment/coefficient and attribute/endowment effect. We summarize our findings in the final section of the paper.

\section{Labor Force Participation Rates}

China's economic reforms have widened the range of women's opportunities for paid employment as the economic structure shifted away from capital-intensive heavy industry towards labor-intensive light industry and commercial services. Economic growth and concomitant wage increases raise the opportunity cost of not working. On this basis, we'd expect to see higher levels of labor force participation in 1990 and 2000 than in 1982, as the gains from such participation increase. China, however, has long had very high labor force participation rates by international standards, especially for women. The labor force participation rates of urban women in 1982 (very early in the reform period) were 87.5 for women age 25-50 and 70.5 for women age 15 and above. ${ }^{7}$ Thus, economic growth may not draw significant numbers

\footnotetext{
${ }^{7}$ Authors' calculations based on the census data.
} 
of new workers into the labor force, as not many adults were outside the labor force in the pre-reform period.

The transition also created new obstacles for women’s labor force participation. The state's retreat from its commitment to socialist ideology and enforcement of workplace protections for women coincided with a reemergence of traditional patriarchal values (Croll, 1995; Entwisle and Henderson, 2000). This retreat combined with growing pressure to reduce the size of the state-owned enterprise work force put pressure on women, especially older women, to leave the labor force and return to more subordinate roles. In many cases, the effort expenditure required at the workplace increased with reform-era changes in workplace discipline, making it more difficult for working women to cope with household responsibilities and thus raising the costs of labor force participation, particularly for married women with young children. We thus add variables to control for the number of children of various age groups.

At the household level, rising incomes of spouses and/or other household members can be viewed as an income effect for married women that would allow some individuals to withdraw from the labor force when their spouses' earnings met household income goals. Labor force participation of married women could decline as a result of this phenomenon. Such a trend, however, might be dampened by China's birth planning policies, implemented first as the wan xi shao policy (later births, longer intervals, fewer children) in 1971 and followed by the even more stringent "one-child" policy of 1979, which drastically reduced total fertility rates and affected the value of time spent in home production. The vast majority of Chinese women continue to marry 
and to raise children but they have far fewer children and are finished with childbearing and childrearing at earlier ages than their mothers and grandmothers.

Education is increasingly rewarded in the Chinese workplace (Maurer-Fazio 1999, Zhang et. al. 2005). We, thus, expect to observe a positive relationship between level of education and labor force participation.

The restructuring of the state-owned sector in the latter half of the 1990s led to the lay off of many millions of urban workers. Extended periods of lay off led, in turn, to withdrawal from the labor force of some of these workers, the discouraged worker effect. The layoffs appeared to fall disproportionately on women and older workers (Giles, Park, and Cai, 2006; and Maurer-Fazio, 2006). We enter a series of age dummies to allow for changing age effects.

Finally, and importantly for the focus of this paper, with a relaxation of the protections afforded workers in the socialist period, managers may have begun to indulge prejudices against particular ethnic groups by refusing to hire or disproportionately laying off members of these groups. If such practices are widespread, members of disadvantaged groups could become 'discouraged workers' and withdraw from the labor force.

\section{Data Description}

The data employed in this project are drawn from the three most recent population censuses of China. Our analysis is based on one percent micro data samples of the 1982 and 1990 censuses and a 0.095 percent micro data sample of the 2000 census. $^{8}$ We use all the data for urban residents available in the 1982 and 2000

\footnotetext{
${ }^{8} 1982$ and 1990 samples were obtained from the Data User Services of China Population Information and Research Center.
} 
census micro samples and take a random $50 \%$ subsample of the urban residents in the 1990 micro sample.

Individuals are considered to be in the labor force if they had a job on the day of the census or if they were unemployed and looking for work at that time. We equate those classified as “waiting for work” in the earlier censuses as seeking employment and thus part of the labor force.

Ethnicity is reported directly on the census questionnaires. The number of ethnic groups is consistent across all 3 censuses. We restrict the ages of the individuals included in our analysis to those between 25 and 50. The lower age bound allows us to focus our analysis on those who have completed their schooling. The upper bound is prescribed by two factors. First, and importantly, the Chinese population census data reports household relationships relative to the household head. This makes it very difficult to accurately assign dependent children to parents in multi-generation, extended households. To reliably sort out which children belong to which adults in the census households we make use of a set of questions related to fertility that is asked only of women aged 15 to $50 .{ }^{9}$ Secondly, women who are considered “ordinary” workers face a retirement age of 50.

For each person in our census samples, we have created a set of variables that characterize ethnicity, the number of adults in the household, the age distribution of children in the household, marital status, ${ }^{10}$ education, ${ }^{11}$ and age.

\footnotetext{
${ }^{9}$ In 1982 and 1990 this set of questions was asked of women age 15 to 64 but in 2000 it was asked only of women age 15 to 50 .

${ }^{10}$ We control not only for marital status but also whether the spouse of a married individual was considered a member of the individual's household for the census enumeration. In 1982 and 1990, individuals away from their registered ( $h u k o u$ ) residence for a year or more were enumerated at their then-current location. In 2000, individuals away from their registered residence for 6 months or more were enumerated at their then-current location.
} 
We also created a set of variables at the prefecture and provincial levels that capture local economic conditions_-provincial per capital urban income, provincial real GDP growth rates over the previous 5 years, and prefectural unemployment rates. $^{12}$ These variables are intended to capture differences in labor market opportunities and the general health of the local economy. ${ }^{13}$

\section{Results and Discussion}

We first estimate logits on labor force participation for 1982, 1990, and 2000 with controls for ethnic group, educational attainment, marital status, household composition, age, and local economic conditions. The results are presented in Tables $1 \mathrm{~A}, 1 \mathrm{~B}$, and $1 \mathrm{C}$. The base case consists of married Han of age category 25 to 29 with junior middle-school education. All explanatory variables are highly significant save for one or two ethnic group indicators in particular years,

Focusing first on the ethnic group indicators, we see that while in 1982 and 1990 Hui and Korean women had labor force participation rates that were indistinguishable from the Han, this changes over the course of the reforms. By 2000, Hui and Korean women, respectively, were 3.5 and 5.5\% less likely to participate in the labor force than Han women. (See Column 4--Marginal Probabilities in Tables 1A-C. $)^{14}$ The vast majority of Koreans live in northeastern China, an area hit hard by

\footnotetext{
${ }^{11}$ We aggregate educational classifications into four categories that are consistent across the census years: primary or less, junior middle school, senior middle school, and post-secondary education. ${ }^{12}$ Prefectures are the administrative units below provinces and above counties.

${ }^{13}$ Provincial per capita urban income was obtained through China Statistical Yearbooks accessed through China Data Online (NBS). The growth rates of annual GDP over the previous five years were obtained through a compendium of GDP statistics released by National Bureau of Statistics (NBS 2004). The prefectural unemployment rate was calculated from the census data itself by aggregating unemployment information for all prefectural residents.

${ }^{14}$ For binary variables, the table entries in the marginal probability column represent the discrete change in probability as the binary independent variable is toggled from zero to one. For continuous variables such as age, the table entries are the change in the probability of labor force participation
} 
the decline of inefficient State-run enterprises. Korean men and women both exhibit steeper declines in participation rates than any other ethnic group studied here.

In 1982 and 1990, Manchu, Mongolian, Uygur women were significantly less likely to be in the labor force than Han women. By 2000, the Manchu women became indistinguishable from Han in terms of labor force participation. The very large gap between Uygur and Han participation in 1982 (21.4\%) was reduced to $12.6 \%$ by 1990 and remained at $12 \%$ through 2000 .

The Zhuang are the only ethnic group with labor force participation rates substantially and significantly higher than that of the Han. Throughout the whole period, Zhuang women's participation rates remained 7.4 to $7.9 \%$ above that of the Han.

As expected, education became an increasingly important determinant of labor force participation. At the beginning of the period, women with post-secondary educations were $6.6 \%$ more likely to be in the labor force than those with junior middle-school educations. By the end of the period, those with post-secondary education were $21.2 \%$ more likely to be in the labor force. Throughout the period, women with pre-school age children were consistently 4 to $5 \%$ less likely to be in the labor force than others.

Women's labor force participation is inversely related to local unemployment rates (suggesting a discouraged-worker effect) and, generally, positively related to the level of provincial urban income and provincial rates of GDP growth. The sample statistics presented in Tables 2A-C reveal a marked decline in urban women's labor sample means. 
force participation between 1990 and 2000 which is not mirrored in the sample statistics for men (Appendix Tables 1A-C).

To better understand whether the differences between Han and ethnic minority participation rates are due to differences in their endowments (education level, marital status, household composition, age structure, and location) or to the coefficients (responses to or treatment) of those attributes, we use the Borooah Iyer decomposition technique. Its coefficient effect is derived by estimating the participation rate that would arise if all the women in the sample were treated as Han and subtracting from this the participation rate that would arise if all women in the sample were treated as one of the ethnic groups, for example, Manchu. Borooah and Iyer refer to this as the difference in synthetic probabilities, or in our case, the difference in synthetic participation rates. The endowment effect is the difference in Han and Manchu participation rates resulting from Han Manchu differences in attributes when evaluated with a common coefficient vector. We estimate the endowment effect by subtracting the difference in Han and Manchu synthetic participation rates from the difference between the actual, observed Han and Manchu participation rates.

In the labor force participation setting, we interpret the coefficient effect to measure the “return,” or “treatment” of women’s average characteristics. If all women had Han average attributes rather than, say Uygur attributes, how would the difference in labor force participation change? We note that this treatment of attributes could be market based (e.g., different returns to education) or cultural (e.g. different attitudes towards market and home production). The attributes effect in our model is broader than in earnings models, as it includes local economic factors in 
addition to personal attributes. Thus, differences in local unemployment rates are part of the attribute effect.

We present pair-wise decompositions for Han and minority women in Table 3 (and Han and minority men in Appendix Table 2). The coefficient effects clearly outweigh the attribute effects in all of our pair-wise comparisons. (The two exceptions are the Han Hui 1982 and 1990 cases -- where Han Hui differences in participation rates are quite trivial, less than one percentage point.) A coefficient effect over $100 \%$ indicates that if all women had Han rather than minority group attributes, the higher labor for participation rate for the Han would be higher still. Han women attributeswhether it is easier to get a job due to employers favoring Han, or, it is easier to get a job because Han women are concentrated in lower unemployment regionsencourage Han labor force participation.

The attribute effects are mostly negative, indicating that differences in average Han and minority personal and economic characteristics tend to reduce the gap between Han and minority labor force participation. The reason for such negative attribute effects could be differences in numbers of young children at home, making labor force participation more difficult, or, minorities could be concentrated in higher unemployment regions, leading discouraged minority workers to drop out of the labor force in greater proportion to the majority Han.

Unfortunately, we cannot distinguish here between positive cultural attitudes and effects of potential employer discrimination. As discussed above, if employers discriminate against minorities in hiring and layoff decisions, minorities may become discouraged workers and drop out of the labor force at rates above that of the Han. Of the groups studied here, Zhuang women alone seem more disposed to participate in 
the labor force than the Han. Their actual rates of participation exceed those of the Han from 6.4 to 9.2 percentage points. The gaps between the observed participation rates of Han and Manchu, Mongolian and, most notably, Uygur women have narrowed over time. Although we may be tempted to speculate whether the attitudes of Han women have changed in ways that make them relatively less inclined to participate or the minorities more inclined to participate, or whether market forces have mitigated manager's potential inclination to discriminate against minorities, the data we are working with don't allow us to distinguish between these factors.

\section{Concluding Comments}

The decision to enter the paid workforce or to engage in home production is a complex combination of economic, social and cultural forces. China's economic reforms have unleashed changes in all of these factors. Rewards to market work have increased with reform for most Chinese women, but re-emergent pre-socialist concepts of gender roles may encourage woman to forego these rewards in favor of home production. Our analysis yields indications that market and social treatment of Han attributes tend to ease women's entry into the labor force, while minority women appear to be rich in levels of those attributes that discourage market work at the margin. Further research is needed to separate the varied influences determining the labor force decisions of Chinese women. 


\section{References}

Borooah, Vani K. and Sriya Iyer. 2005. "The decomposition of inter-group differences in a logit model: Extending the Oaxaca-Blinder approach with an application to school enrollment in India,” Journal of Economic and Social Measurement, Vol. 30, No. 4, pp.279-293.

Constitution of the People's Republic of China http://english.peopledaily.com.cn/constitution/constitution.html

Ding, Sai and Shi Li, January 2009, “An Empirical Analysis of Income Inequality between a Minority and Majority in Urban China: The Case of the Ningxia Hui Autonomous Region,” Global COE Hi-Stat Discussion Paper Series 022, Hitotsubashi University, pp. 1-26.

Gustaffson, Bjorn and Sai Ding. October 2008. "Temporary and Persistent Poverty among Ethnic Minorities and the Majority in Rural China,” IZA Discussion Paper 3791, pp. 1-31.

Gustaffson, Bjorn and Shi Li. 1998. "Inequality in China at the End of the 1980s: Locational Aspects and Household Chararcteristics," Asian Economic Journal. Vol. 12, No. 1. pp 35-62.

Gustafsson, Bjorn and Shi Li, “The Ethnic Minority-Majority Income Gap in Rural China During Transition,” Economic Development and Cultural Change, July 2003, Volume 51, Issue 4, pp.805-822.

Hannum, Emily and Yu Xie, "Ethnic Stratification in Northwest China: Occupational Differences between Han Chinese and National Minorities in Xinjiang, 1982-1990," Demography, Volume 35, Issue 3, August 1998, pp.323-333.

Hoddie, Matthew, “Ethnic Identity Change in the People’s Republic of China: An Explanation Using Data from the 1982 and 1990 Census Enumerations,” in William Safran (ed.) Nationalism and Ethnoregional Identities in China, Frank Cass: London, 1998.

Information Office of the State Council of the People's Republic of China, National Minorities Policy and Its Practice in China. Beijing. 1999

Mackerras, Colin. China's Ethnic Minorities and Globalization, RoutledgeCurzon: London and New York, 2003.

Maurer-Fazio, Margaret "Education and Earnings in China's Transition to a Market Economy: Survey Evidence from 1989 and 1992,” China Economic Review, 1999. Volume 10, No. 1, pp.17-40. 
Maurer-Fazio, Margaret "In Books One Finds a House of Gold: The Role of Education in Labor Market Outcomes in Urban China," the Journal of Contemporary China, August 2006, Volume 15, Number 47, pp. 215-231.

Maurer-Fazio, Margaret, James Hughes, and Dandan Zhang, “An Ocean Formed from One Hundred Rivers: The Effects of Ethnicity, Gender, Marriage, and Location on Labor Force Participation in Urban China,” Feminist Economics, July/October 2007, 13(3-4), 125-153.

NBS. National Bureau of Statistics of China, China Statistical Yearbooks, accessed through China Data Online to provincial statistics/ people's livelihood and worker's wage/basic statistics for people's livelihood/

NBS. National Bureau of Statistics of China, Data of gross domestic product of China, 1996-2002, Beijing: China Statistics Press, 2004.

NBS and SEAC. National Bureau of Statistic, P.R.C Department of Population, Social Science, and Technology Statistics and State Ethnic Affairs Commission, Department of Economic Development, The Tabulation on Nationalities of 2000 Population Census of China, Ethnic Publishing House: Beijing, 2003.

Sautman, Barry, "Preferential Policies for Ethnic Minorities in China: the Case of Xinjiang," in William Safran (ed.) Nationalism and Ethnoregional Identities in China, Frank Cass: London, 1998.

SEAC. State Ethnic Affairs Committee, China's Yearbook of Ethnic Works 2003, Beijing 2003.

SEAC and NBS. State Ethnic Affairs Committee, Department of Economic Development and National Bureau of Statistics, P.R.C., Department of Integrated Statistics, China's Ethnic Statistical Yearbook, 2000, Ethnic Publishing House: Beijing, 2000.

Zhang Junsen, Zhao Yaohui, Park, Albert and Song Xiaoqing, 2005. "Economic Returns to Education in Urban China, 1988 to 2001," Journal of Comparative Economics Volume 33, Number 4, pp. 730-752. 
Data Sources for Tables: 1\% Micro samples of the Population Censuses of China for the years 1982 and 1990, and 0.095\% Micro sample of the Population Census of China 2000. 
Table 1-A

Labor Force Participation of Chinese Urban Women, Age 25-50, in 1982 Logistic Regressions and Marginal Effects

\begin{tabular}{|c|c|c|c|c|c|}
\hline Variables & Coefficient & $\begin{array}{c}\text { Robust } \\
\text { Standard }\end{array}$ & Z Values & $\begin{array}{c}\text { Marginal } \\
\text { Probability }\end{array}$ & X-Bar \\
\hline \multicolumn{6}{|l|}{ Ethnic Group } \\
\hline Hui & 0.049 & 0.056 & 0.880 & 0.004 & 0.013 \\
\hline Korean & 0.192 & 0.109 & 1.770 & 0.015 & 0.004 \\
\hline Manchu & -0.442 & 0.081 & -5.480 & -0.043 & 0.005 \\
\hline Mongolian & -0.804 & 0.123 & -6.550 & -0.091 & 0.002 \\
\hline Uygur & -1.487 & 0.094 & -15.850 & -0.214 & 0.003 \\
\hline Zhuang & 1.793 & 0.159 & 11.280 & 0.074 & 0.003 \\
\hline other ethnic minorities & 1.171 & 0.125 & 9.370 & 0.061 & 0.005 \\
\hline \multicolumn{6}{|l|}{ Educational Attainment } \\
\hline primary school or less & -0.771 & 0.016 & -48.740 & -0.077 & 0.199 \\
\hline \multicolumn{6}{|l|}{ base case: junior middle school } \\
\hline senior middle school & 1.309 & 0.034 & 38.230 & 0.075 & 0.139 \\
\hline post-secondary education & 1.318 & 0.070 & 18.890 & 0.066 & 0.029 \\
\hline \multicolumn{6}{|l|}{ Marital Status } \\
\hline not married & -0.058 & 0.031 & -1.920 & -0.005 & 0.066 \\
\hline \multicolumn{6}{|l|}{ base case: married spouse present } \\
\hline married spouse elsewhere & -0.183 & 0.019 & -9.450 & -0.016 & 0.166 \\
\hline \multicolumn{6}{|l|}{ Household Composition } \\
\hline Number of adults (age 18 and over) & -0.087 & 0.006 & -15.300 & -0.007 & 2.759 \\
\hline number of children age 0 to 5 & -0.470 & 0.014 & -33.280 & -0.039 & 0.421 \\
\hline number of children age 6 to 12 & -0.146 & 0.009 & -16.160 & -0.012 & 0.678 \\
\hline number of children age 13 to 17 & 0.063 & 0.017 & 3.800 & 0.005 & 0.305 \\
\hline \multicolumn{6}{|l|}{ Age Category } \\
\hline \multicolumn{6}{|l|}{ base case: age 25 to 29} \\
\hline age 30 to 34 & 0.092 & 0.023 & 3.940 & 0.007 & 0.216 \\
\hline age 35 to 39 & -0.215 & 0.029 & -7.530 & -0.019 & 0.160 \\
\hline age 40 to 44 & -0.614 & 0.028 & -22.230 & -0.060 & 0.161 \\
\hline age 45 to 50 & -1.762 & 0.025 & -71.170 & -0.228 & 0.181 \\
\hline \multicolumn{6}{|l|}{ Economic Environment } \\
\hline prefectural unemployment rate & -0.221 & 0.006 & -38.490 & -0.018 & 1.577 \\
\hline provincial real per capita income & 0.112 & 0.003 & 35.350 & 0.009 & 10.168 \\
\hline provincial real 5-year GDP growth & 0.123 & 0.004 & 28.030 & 0.010 & 9.158 \\
\hline Constant & 1.307 & 0.060 & 21.650 & & \\
\hline \multicolumn{6}{|l|}{ Summary Statistics } \\
\hline Mean Ifp & & & & 0.873 & \\
\hline Predicted Ifp & & & & 0.910 & \\
\hline Log pseudolikelihood & -79611.705 & & & & \\
\hline Number of observations & 245,402 & & & & \\
\hline Wald chi2(23) $=$ & 23,942 & & & & \\
\hline Prob $>$ chi2 $=$ & 0.000 & & & & \\
\hline Pseudo R2 & 0.149 & & & & \\
\hline
\end{tabular}


Table 1-B

Labor Force Participation of Chinese Urban Women, Age 25-50 in 1990 Logistic Regressions and Marginal Effects

\begin{tabular}{|c|c|c|c|c|c|}
\hline Variables & Coefficient & $\begin{array}{c}\text { Robust } \\
\text { Standard }\end{array}$ & Z Values & $\begin{array}{c}\text { Marginal } \\
\text { Probability }\end{array}$ & X-Bar \\
\hline \multicolumn{6}{|l|}{ Ethnic Group } \\
\hline Hui & 0.095 & 0.056 & 1.710 & 0.008 & 0.010 \\
\hline Korean & -0.084 & 0.098 & -0.850 & -0.008 & 0.003 \\
\hline Manchu & -0.683 & 0.045 & -15.190 & -0.080 & 0.010 \\
\hline Mongolian & -1.096 & 0.065 & -16.810 & -0.150 & 0.005 \\
\hline Uygur & -0.965 & 0.066 & -14.530 & -0.126 & 0.004 \\
\hline Zhuang & 1.535 & 0.089 & 17.180 & 0.079 & 0.011 \\
\hline other ethnic minorities & -0.034 & 0.047 & -0.730 & -0.003 & 0.015 \\
\hline \multicolumn{6}{|l|}{ Educational Attainment } \\
\hline primary school or less & -0.546 & 0.015 & -35.780 & -0.059 & 0.115 \\
\hline \multicolumn{6}{|l|}{ base case: junior middle school } \\
\hline senior middle school & 1.276 & 0.020 & 64.150 & 0.091 & 0.236 \\
\hline post-secondary education & 2.653 & 0.081 & 32.580 & 0.102 & 0.040 \\
\hline \multicolumn{6}{|l|}{ Marital Status } \\
\hline not married & 0.133 & 0.031 & 4.220 & 0.011 & 0.042 \\
\hline \multicolumn{6}{|l|}{ base case: married spouse present } \\
\hline married spouse elsewhere & -0.025 & 0.022 & -1.130 & -0.002 & 0.085 \\
\hline \multicolumn{6}{|l|}{ Household Composition } \\
\hline Number of adults (age 18 and over) & -0.040 & 0.005 & -7.290 & -0.004 & 2.620 \\
\hline number of children age 0 to 5 & -0.410 & 0.011 & -37.550 & -0.037 & 0.405 \\
\hline number of children age 6 to 12 & -0.235 & 0.010 & -24.460 & -0.021 & 0.534 \\
\hline number of children age 13 to 17 & -0.143 & 0.015 & -9.720 & -0.013 & 0.249 \\
\hline \multicolumn{6}{|l|}{ Age Category } \\
\hline \multicolumn{6}{|l|}{ base case: age 25 to 29} \\
\hline age 30 to 34 & 0.174 & 0.020 & 8.610 & 0.015 & 0.224 \\
\hline age 35 to 39 & 0.153 & 0.022 & 6.910 & 0.013 & 0.222 \\
\hline age 40 to 44 & -0.320 & 0.024 & -13.550 & -0.032 & 0.155 \\
\hline age 45 to 50 & -1.295 & 0.022 & -58.880 & -0.169 & 0.140 \\
\hline \multicolumn{6}{|l|}{ Economic Environment } \\
\hline prefectural unemployment rate & -0.250 & 0.004 & -65.030 & -0.023 & 1.269 \\
\hline provincial real per capita income & 0.015 & 0.000 & 34.480 & 0.001 & 55.606 \\
\hline provincial real 5-year GDP growth & -0.067 & 0.004 & -16.650 & -0.006 & 5.956 \\
\hline Constant & 2.309 & 0.040 & 57.690 & & \\
\hline \multicolumn{6}{|l|}{ Summary Statistics } \\
\hline Mean Ifp & & & & 0.864 & \\
\hline Predicted Ifp & & & & 0.899 & \\
\hline Log pseudolikelihood & -16561.750 & & & & \\
\hline Number of observations & 303,694 & & & & \\
\hline Wald chi2(23) $=$ & 22,900 & & & & \\
\hline Prob $>$ chi2 $=$ & 0.000 & & & & \\
\hline Pseudo R2 & 0.120 & & & & \\
\hline
\end{tabular}


Table 1-C

Labor Force Participation of Chinese Urban Women, Age 25-50 in 2000 Logistic Regressions and Marginal Effects

\begin{tabular}{|c|c|c|c|c|c|}
\hline Variables & Coefficient & $\begin{array}{c}\text { Robust } \\
\text { Standard }\end{array}$ & Z Values & $\begin{array}{c}\text { Marginal } \\
\text { Probability }\end{array}$ & X-Bar \\
\hline \multicolumn{6}{|l|}{ Ethnic Group } \\
\hline Hui & -0.200 & 0.078 & -2.560 & -0.035 & 0.010 \\
\hline Korean & -0.304 & 0.153 & -1.980 & -0.055 & 0.003 \\
\hline Manchu & 0.001 & 0.083 & 0.010 & 0.000 & 0.009 \\
\hline Mongolian & -0.316 & 0.114 & -2.770 & -0.057 & 0.005 \\
\hline Uygur & -0.619 & 0.122 & -5.080 & -0.120 & 0.004 \\
\hline Zhuang & 0.563 & 0.109 & 5.160 & 0.079 & 0.007 \\
\hline other ethnic minorities & 0.176 & 0.071 & 2.460 & 0.028 & 0.015 \\
\hline \multicolumn{6}{|l|}{ Educational Attainment } \\
\hline primary school or less & -0.216 & 0.040 & -5.390 & -0.038 & 0.034 \\
\hline \multicolumn{6}{|l|}{ base case: junior middle school } \\
\hline senior middle school & 0.664 & 0.021 & 32.280 & 0.100 & 0.251 \\
\hline post-secondary education & 2.193 & 0.052 & 41.850 & 0.212 & 0.099 \\
\hline \multicolumn{6}{|l|}{ Marital Status } \\
\hline not married & 0.437 & 0.041 & 10.580 & 0.064 & 0.057 \\
\hline \multicolumn{6}{|l|}{ base case: married spouse present } \\
\hline married spouse elsewhere & 0.047 & 0.034 & 1.410 & 0.008 & 0.071 \\
\hline \multicolumn{6}{|l|}{ Household Composition } \\
\hline Number of adults (age 18 and over) & 0.085 & 0.009 & 9.370 & 0.014 & 2.510 \\
\hline number of children age 0 to 5 & -0.302 & 0.021 & -14.160 & -0.050 & 0.225 \\
\hline number of children age 6 to 12 & -0.043 & 0.016 & -2.710 & -0.007 & 0.410 \\
\hline number of children age 13 to 17 & 0.115 & 0.022 & 5.130 & 0.019 & 0.221 \\
\hline \multicolumn{6}{|l|}{ Age Category } \\
\hline \multicolumn{6}{|l|}{ base case: age 25 to 29} \\
\hline age 30 to 34 & 0.080 & 0.027 & 2.900 & 0.013 & 0.227 \\
\hline age 35 to 39 & 0.062 & 0.031 & 2.000 & 0.010 & 0.210 \\
\hline age 40 to 44 & -0.208 & 0.032 & -6.480 & -0.036 & 0.166 \\
\hline age 45 to 50 & -0.955 & 0.029 & -33.030 & -0.184 & 0.184 \\
\hline \multicolumn{6}{|l|}{ Economic Environment } \\
\hline prefectural unemployment rate & -0.068 & 0.002 & -27.620 & -0.011 & 4.779 \\
\hline provincial real per capita income & 0.003 & 0.000 & 7.140 & 0.001 & 65.563 \\
\hline provincial real 5-year GDP growth & 0.068 & 0.007 & 9.500 & 0.011 & 9.057 \\
\hline Constant & 0.431 & 0.075 & 5.780 & & \\
\hline \multicolumn{6}{|l|}{ Summary Statistics } \\
\hline Mean Ifp & & & & 0.762 & \\
\hline Predicted Ifp & & & & 0.790 & \\
\hline Log pseudolikelihood & -47140.171 & & & & \\
\hline Number of observations & 93,145 & & & & \\
\hline Wald chi2(23) $=$ & 6,183 & & & & \\
\hline Prob $>$ chi2 $=$ & 0.000 & & & & \\
\hline Pseudo R2 & 0.077 & & & & \\
\hline
\end{tabular}


Table 2-A

Sample Statistics Urban Women Age 25-50 in 1982

\begin{tabular}{|c|c|c|c|c|c|c|c|}
\hline Variable & Han & Hui & Korean & Manchu & Mongolian & Uygur & Zhuang \\
\hline Labor force participation rate & 0.873 & 0.878 & 0.874 & 0.803 & 0.773 & 0.666 & 0.937 \\
\hline primary or less & 0.511 & 0.472 & 0.277 & 0.378 & 0.459 & 0.637 & 0.693 \\
\hline junior middle school & 0.322 & 0.370 & 0.457 & 0.404 & 0.257 & 0.227 & 0.181 \\
\hline senior middle school & 0.139 & 0.132 & 0.236 & 0.183 & 0.221 & 0.116 & 0.112 \\
\hline \multicolumn{8}{|l|}{ Marital Status, proportion: } \\
\hline not married & 0.066 & 0.073 & 0.045 & 0.071 & 0.070 & 0.123 & 0.063 \\
\hline married, spouse not present & 0.167 & 0.135 & 0.107 & 0.136 & 0.101 & 0.074 & 0.166 \\
\hline \multicolumn{8}{|l|}{ Household compostion, mean: } \\
\hline \multicolumn{8}{|l|}{ Age, proportion this category: } \\
\hline 25 to 29 & 0.283 & 0.266 & 0.307 & 0.309 & 0.302 & 0.265 & 0.300 \\
\hline 30 to 34 & 0.216 & 0.228 & 0.203 & 0.195 & 0.194 & 0.191 & 0.216 \\
\hline 35 to 39 & 0.160 & 0.175 & 0.129 & 0.137 & 0.162 & 0.186 & 0.144 \\
\hline 40 to 44 & 0.160 & 0.165 & 0.168 & 0.163 & 0.182 & 0.170 & 0.172 \\
\hline 45 to 50 & 0.181 & 0.166 & 0.193 & 0.196 & 0.160 & 0.188 & 0.168 \\
\hline Prefectural Unemployment Rates & $1.57 \%$ & $1.67 \%$ & $2.44 \%$ & $2.25 \%$ & $2.02 \%$ & $1.11 \%$ & $2.84 \%$ \\
\hline Number of Observations & 236,885 & 3191 & 876 & 1260 & 444 & 775 & 814 \\
\hline
\end{tabular}


Table 2-B

Sample Statistics Urban Women Age 25-50 in 1990

\begin{tabular}{|c|c|c|c|c|c|c|c|}
\hline Variable & Han & Hui & Korean & Manchu & Mongolian & Uygur & Zhuang \\
\hline Labor force participation rate & 0.866 & 0.858 & 0.831 & 0.770 & 0.706 & 0.587 & 0.957 \\
\hline primary or less & 0.379 & 0.323 & 0.178 & 0.351 & 0.318 & 0.465 & 0.656 \\
\hline junior middle school & 0.343 & 0.393 & 0.421 & 0.346 & 0.310 & 0.254 & 0.224 \\
\hline senior middle school & 0.238 & 0.243 & 0.336 & 0.254 & 0.315 & 0.232 & 0.114 \\
\hline \multicolumn{8}{|l|}{ Marital Status, proportion: } \\
\hline not married & 0.040 & 0.055 & 0.062 & 0.035 & 0.040 & 0.134 & 0.060 \\
\hline married, spouse not present & 0.086 & 0.087 & 0.033 & 0.044 & 0.042 & 0.070 & 0.073 \\
\hline \multicolumn{8}{|l|}{ Household compostion, mean: } \\
\hline \multicolumn{8}{|l|}{ Age, proportion this category: } \\
\hline 25 to 29 & 0.258 & 0.255 & 0.262 & 0.305 & 0.344 & 0.275 & 0.282 \\
\hline 30 to 34 & 0.224 & 0.220 & 0.268 & 0.245 & 0.256 & 0.215 & 0.197 \\
\hline 35 to 39 & 0.223 & 0.228 & 0.199 & 0.209 & 0.181 & 0.167 & 0.196 \\
\hline 40 to 44 & 0.155 & 0.162 & 0.144 & 0.126 & 0.109 & 0.175 & 0.164 \\
\hline 45 to 50 & 0.140 & 0.136 & 0.127 & 0.115 & 0.111 & 0.169 & 0.161 \\
\hline Prefectural Unemployment Rates & $1.27 \%$ & $1.69 \%$ & $2.36 \%$ & $1.51 \%$ & $1.02 \%$ & $2.43 \%$ & $1.08 \%$ \\
\hline Number of Observations & 286,173 & 2922 & 866 & 3133 & 1373 & 1304 & 3388 \\
\hline
\end{tabular}


Table 2-C

Sample Statistics Urban Women Age 25-50 in 2000

\begin{tabular}{|c|c|c|c|c|c|c|c|}
\hline Variable & Han & Hui & Korean & Manchu & Mongolian & Uygur & Zhuang \\
\hline Labor force participation rate & 0.763 & 0.721 & 0.676 & 0.721 & 0.718 & 0.648 & 0.836 \\
\hline primary or less & 0.228 & 0.227 & 0.063 & 0.170 & 0.155 & 0.271 & 0.320 \\
\hline junior middle school & 0.423 & 0.409 & 0.415 & 0.445 & 0.343 & 0.295 & 0.411 \\
\hline senior middle school & 0.251 & 0.263 & 0.375 & 0.255 & 0.345 & 0.286 & 0.196 \\
\hline \multicolumn{8}{|l|}{ Marital Status, proportion: } \\
\hline not married & 0.056 & 0.060 & 0.119 & 0.064 & 0.039 & 0.108 & 0.086 \\
\hline married, spouse not present & 0.071 & 0.076 & 0.079 & 0.038 & 0.039 & 0.036 & 0.071 \\
\hline \multicolumn{8}{|l|}{ Household compostion, mean: } \\
\hline \multicolumn{8}{|l|}{ Age, proportion this category: } \\
\hline 25 to 29 & 0.211 & 0.212 & 0.162 & 0.202 & 0.270 & 0.268 & 0.246 \\
\hline 30 to 34 & 0.227 & 0.205 & 0.198 & 0.228 & 0.198 & 0.247 & 0.237 \\
\hline 35 to 39 & 0.210 & 0.226 & 0.269 & 0.222 & 0.205 & 0.202 & 0.208 \\
\hline 40 to 44 & 0.167 & 0.161 & 0.194 & 0.181 & 0.180 & 0.151 & 0.149 \\
\hline 45 to 50 & 0.186 & 0.196 & 0.178 & 0.167 & 0.148 & 0.133 & 0.161 \\
\hline Prefectural Unemployment Rates & $4.78 \%$ & $4.52 \%$ & $9.43 \%$ & $8.08 \%$ & $5.47 \%$ & $3.92 \%$ & $3.26 \%$ \\
\hline Number of Observations & 88,332 & 902 & 253 & 843 & 440 & 332 & 659 \\
\hline
\end{tabular}


Table 3

Decomposition of Differences in Chinese Women's Labor Force Participation Rates Urban Women Age 25-50

\begin{tabular}{|l|c|c|c|c|c|}
\hline \multicolumn{1}{|c|}{$\mathbf{1 9 8 2}$} & $\begin{array}{c}\text { LFP Rate } \\
\text { Differences }\end{array}$ & $\begin{array}{c}\text { Coefficients } \\
\text { Effect }\end{array}$ & $\begin{array}{c}\text { Coefficient } \\
\text { \% }\end{array}$ & $\begin{array}{c}\text { Endowment } \\
\text { Effect }\end{array}$ & $\begin{array}{c}\text { Endowment } \\
\%\end{array}$ \\
\hline Han-Hui & -0.0044 & -0.0018 & $39.99 \%$ & -0.0027 & $60.01 \%$ \\
\hline Han-Korean & -0.0011 & -0.0051 & $480.23 \%$ & 0.0040 & $-380.23 \%$ \\
\hline Han-Manchu & 0.0702 & 0.0944 & $134.56 \%$ & -0.0243 & $-34.56 \%$ \\
\hline Han-Mongolian & 0.1008 & 0.1179 & $116.90 \%$ & -0.0170 & $-16.90 \%$ \\
\hline Han-Uygur & 0.2076 & 0.2585 & $124.53 \%$ & -0.0509 & $-24.53 \%$ \\
\hline Han-Zhuang & -0.0640 & -0.0681 & $106.42 \%$ & 0.0041 & $-6.42 \%$ \\
\hline
\end{tabular}

\begin{tabular}{|l|c|c|c|c|c|}
\hline \multicolumn{1}{|c|}{$\mathbf{1 9 9 0}$} & $\begin{array}{c}\text { LFP Rate } \\
\text { Differences }\end{array}$ & $\begin{array}{c}\text { Coefficients } \\
\text { Effect }\end{array}$ & $\begin{array}{c}\text { Coefficient } \\
\%\end{array}$ & $\begin{array}{c}\text { End owment } \\
\text { Effect }\end{array}$ & $\begin{array}{c}\text { Endowment } \\
\%\end{array}$ \\
\hline Han-Hui & 0.0079 & 0.0009 & $10.91 \%$ & 0.0070 & $89.09 \%$ \\
\hline Han-Korean & 0.0345 & 0.0698 & $202.54 \%$ & -0.0353 & $-102.54 \%$ \\
\hline Han-Manchu & 0.0960 & 0.0956 & $99.61 \%$ & 0.0004 & $0.39 \%$ \\
\hline Han-Mongolian & 0.1601 & 0.1635 & $102.11 \%$ & -0.0034 & $-2.11 \%$ \\
\hline Han-Uygur & 0.2784 & 0.2742 & $98.49 \%$ & 0.0042 & $1.51 \%$ \\
\hline Han-Zhuang & -0.0916 & -0.0785 & $85.63 \%$ & -0.0132 & $14.37 \%$ \\
\hline
\end{tabular}

\begin{tabular}{|l|c|c|c|c|c|}
\hline \multicolumn{1}{|c|}{$\mathbf{2 0 0 0}$} & $\begin{array}{c}\text { LFP Rate } \\
\text { Differences }\end{array}$ & $\begin{array}{c}\text { Coefficients } \\
\text { Effect }\end{array}$ & $\begin{array}{c}\text { Coefficient } \\
\text { \% }\end{array}$ & $\begin{array}{c}\text { End owment } \\
\text { Effect }\end{array}$ & $\begin{array}{c}\text { Endowment } \\
\%\end{array}$ \\
\hline Han-Hui & 0.0423 & 0.0473 & $111.91 \%$ & -0.0050 & $-11.91 \%$ \\
\hline Han-Korean & 0.0870 & 0.1050 & $120.69 \%$ & -0.0180 & $-20.69 \%$ \\
\hline Han-Manchu & 0.0417 & 0.0406 & $97.43 \%$ & 0.0011 & $2.57 \%$ \\
\hline Han-Mongolian & 0.0447 & 0.0849 & $189.76 \%$ & -0.0401 & $-89.76 \%$ \\
\hline Han-Uygur & 0.1153 & 0.1634 & $141.70 \%$ & -0.0481 & $-41.70 \%$ \\
\hline Han-Zhuang & -0.0732 & -0.0758 & $103.49 \%$ & 0.0026 & $-3.49 \%$ \\
\hline
\end{tabular}


Appendix Table 1-A

Sample Statistics Urban Men Age 25-50 in 1982

\begin{tabular}{|c|c|c|c|c|c|c|c|}
\hline Variable & Han & Hui & Korean & Manchu & Mongolian & Uygur & Zhuang \\
\hline Labor force participation rate & 0.988 & 0.983 & 0.980 & 0.989 & 0.989 & 0.988 & 0.976 \\
\hline \multicolumn{8}{|l|}{ Education level, proportion with: } \\
\hline primary or less & 0.359 & 0.347 & 0.118 & 0.274 & 0.358 & 0.587 & 0.478 \\
\hline junior middle school & 0.405 & 0.432 & 0.455 & 0.442 & 0.319 & 0.259 & 0.335 \\
\hline senior middle school & 0.172 & 0.165 & 0.311 & 0.213 & 0.223 & 0.121 & 0.132 \\
\hline post secondary & 0.064 & 0.056 & 0.116 & 0.071 & 0.100 & 0.034 & 0.055 \\
\hline \multicolumn{8}{|l|}{ Marital Status, proportion: } \\
\hline not married & 0.129 & 0.118 & 0.075 & 0.084 & 0.087 & 0.130 & 0.114 \\
\hline married, spouse not present & 0.105 & 0.097 & 0.071 & 0.074 & 0.046 & 0.110 & 0.066 \\
\hline \multicolumn{8}{|l|}{ Household compostion, mean: } \\
\hline number of adults (age $18+$ ) & 2.786 & 2.793 & 2.856 & 2.851 & 2.720 & 2.585 & 2.925 \\
\hline number of children age 0 to 5 & 0.390 & 0.409 & 0.425 & 0.404 & 0.497 & 0.770 & 0.775 \\
\hline number of children age 6 to 12 & 0.582 & 0.594 & 0.590 & 0.606 & 0.699 & 0.881 & 0.844 \\
\hline number of children age 13 to 17 & 0.242 & 0.244 & 0.273 & 0.251 & 0.260 & 0.262 & 0.277 \\
\hline \multicolumn{8}{|l|}{ Age, proportion this category: } \\
\hline 25 to 29 & 0.284 & 0.271 & 0.276 & 0.281 & 0.271 & 0.255 & 0.281 \\
\hline 30 to 34 & 0.213 & 0.220 & 0.237 & 0.208 & 0.191 & 0.211 & 0.229 \\
\hline 35 to 39 & 0.152 & 0.150 & 0.136 & 0.154 & 0.157 & 0.170 & 0.121 \\
\hline 40 to 44 & 0.154 & 0.174 & 0.167 & 0.160 & 0.185 & 0.166 & 0.166 \\
\hline 45 to 50 & 0.198 & 0.185 & 0.183 & 0.197 & 0.196 & 0.197 & 0.202 \\
\hline Prefectural Unemployment Rates & $1.58 \%$ & $1.67 \%$ & $2.46 \%$ & $2.29 \%$ & $1.98 \%$ & $1.15 \%$ & $2.74 \%$ \\
\hline Number of Observations & 218,846 & 2984 & 785 & 1515 & 439 & 745 & 668 \\
\hline
\end{tabular}


Appendix Table 1-B

Sample Statistics Urban Men Age 25-50 in 1990

\begin{tabular}{|c|c|c|c|c|c|c|c|}
\hline Variable & Han & Hui & Korean & Manchu & Mongolian & Uygur & Zhuang \\
\hline Labor force participation rate & 0.991 & 0.987 & 0.983 & 0.992 & 0.982 & 0.967 & 0.991 \\
\hline \multicolumn{8}{|l|}{ Education level, proportion with: } \\
\hline primary or less & 0.252 & 0.242 & 0.094 & 0.248 & 0.182 & 0.378 & 0.409 \\
\hline junior middle school & 0.404 & 0.449 & 0.428 & 0.430 & 0.356 & 0.286 & 0.370 \\
\hline senior middle school & 0.261 & 0.247 & 0.375 & 0.248 & 0.347 & 0.228 & 0.192 \\
\hline post secondary & 0.083 & 0.062 & 0.103 & 0.074 & 0.116 & 0.107 & 0.030 \\
\hline \multicolumn{8}{|l|}{ Marital Status, proportion: } \\
\hline not married & 0.090 & 0.081 & 0.101 & 0.081 & 0.065 & 0.147 & 0.107 \\
\hline married, spouse not present & 0.051 & 0.056 & 0.019 & 0.029 & 0.028 & 0.081 & 0.032 \\
\hline \multicolumn{8}{|l|}{ Household compostion, mean: } \\
\hline number of adults (age 18+) & 2.604 & 2.599 & 2.662 & 2.595 & 2.592 & 2.556 & 2.976 \\
\hline number of children age 0 to 5 & 0.407 & 0.437 & 0.419 & 0.430 & 0.598 & 0.802 & 0.666 \\
\hline number of children age 6 to 12 & 0.492 & 0.517 & 0.479 & 0.522 & 0.678 & 0.729 & 0.850 \\
\hline number of children age 13 to 17 & 0.207 & 0.206 & 0.203 & 0.198 & 0.171 & 0.216 & 0.245 \\
\hline \multicolumn{8}{|l|}{ Age, proportion this category: } \\
\hline 25 to 29 & 0.251 & 0.249 & 0.229 & 0.263 & 0.313 & 0.275 & 0.280 \\
\hline 30 to 34 & 0.228 & 0.224 & 0.275 & 0.266 & 0.273 & 0.230 & 0.193 \\
\hline 35 to 39 & 0.222 & 0.220 & 0.227 & 0.219 & 0.215 & 0.174 & 0.211 \\
\hline 40 to 44 & 0.159 & 0.162 & 0.139 & 0.131 & 0.101 & 0.171 & 0.170 \\
\hline 45 to 50 & 0.141 & 0.145 & 0.130 & 0.121 & 0.099 & 0.150 & 0.147 \\
\hline Prefectural Unemployment Rates & $1.27 \%$ & $1.60 \%$ & $2.32 \%$ & $1.56 \%$ & $1.02 \%$ & $2.49 \%$ & $1.08 \%$ \\
\hline Number of Observations & 282,720 & 2975 & 841 & 3408 & 1298 & 1296 & 2996 \\
\hline
\end{tabular}


Appendix Table 1-C

Sample Statistics Urban Men Age 25-50 in 2000

\begin{tabular}{|c|c|c|c|c|c|c|c|}
\hline Variable & Han & Hui & Korean & Manchu & Mongolian & Uygur & Zhuang \\
\hline Labor force participation rate & 0.962 & 0.943 & 0.879 & 0.961 & 0.951 & 0.928 & 0.971 \\
\hline primary or less & 0.137 & 0.179 & 0.030 & 0.126 & 0.065 & 0.257 & 0.168 \\
\hline junior middle school & 0.441 & 0.447 & 0.358 & 0.460 & 0.322 & 0.329 & 0.405 \\
\hline senior middle school & 0.271 & 0.240 & 0.457 & 0.243 & 0.371 & 0.271 & 0.269 \\
\hline \multicolumn{8}{|l|}{ Marital Status, proportion: } \\
\hline not married & 0.090 & 0.106 & 0.185 & 0.083 & 0.070 & 0.116 & 0.122 \\
\hline married, spouse not present & 0.053 & 0.057 & 0.052 & 0.031 & 0.022 & 0.021 & 0.073 \\
\hline \multicolumn{8}{|l|}{ Household compostion, mean: } \\
\hline \multicolumn{8}{|l|}{ Age, proportion this category: } \\
\hline 25 to 29 & 0.198 & 0.209 & 0.151 & 0.168 & 0.238 & 0.250 & 0.227 \\
\hline 30 to 34 & 0.226 & 0.219 & 0.211 & 0.242 & 0.211 & 0.257 & 0.255 \\
\hline 35 to 39 & 0.215 & 0.201 & 0.259 & 0.217 & 0.217 & 0.229 & 0.198 \\
\hline 40 to 44 & 0.173 & 0.154 & 0.224 & 0.182 & 0.192 & 0.151 & 0.155 \\
\hline 45 to 50 & 0.188 & 0.217 & 0.155 & 0.191 & 0.141 & 0.113 & 0.165 \\
\hline Prefectural Unemployment Rates & $4.79 \%$ & $4.64 \%$ & $9.65 \%$ & $8.25 \%$ & $5.59 \%$ & $3.88 \%$ & $3.24 \%$ \\
\hline Number of Observations & 87,393 & 912 & 232 & 828 & 369 & 292 & 647 \\
\hline
\end{tabular}


Appendix Table 2

Decomposition of Differences in Chinese Men's Labor Force Participation Rates

Urban Men Age 25-50

\begin{tabular}{|l|c|c|c|c|c|}
\hline \multicolumn{1}{|c|}{$\mathbf{1 9 8 2}$} & $\begin{array}{c}\text { LFP Rate } \\
\text { Differences }\end{array}$ & $\begin{array}{c}\text { Coefficients } \\
\text { Effect }\end{array}$ & $\begin{array}{c}\text { Coefficient } \\
\%\end{array}$ & $\begin{array}{c}\text { Endowment } \\
\text { Effect }\end{array}$ & $\begin{array}{c}\text { Endowment } \\
\%\end{array}$ \\
\hline Han-Hui & 0.0051 & 0.0065 & $126.56 \%$ & -0.0014 & $-26.56 \%$ \\
\hline Han-Korean & 0.0081 & 0.0137 & $169.29 \%$ & -0.0056 & $-69.29 \%$ \\
\hline Han-Manchu & -0.0011 & 0.0021 & $-189.54 \%$ & -0.0032 & $289.54 \%$ \\
\hline Han-Mongolian & -0.0009 & 0.0006 & $-62.86 \%$ & -0.0015 & $162.86 \%$ \\
\hline Han-Uygur & -0.0002 & 0.0413 & $-18011.43 \%$ & -0.0416 & $18111.43 \%$ \\
\hline Han-Zhuang & 0.0116 & 0.0080 & $68.62 \%$ & 0.0037 & $31.38 \%$ \\
\hline
\end{tabular}

\begin{tabular}{|l|c|c|c|c|c|}
\hline \multicolumn{1}{|c|}{$\mathbf{1 9 9 0}$} & $\begin{array}{c}\text { LFP Rate } \\
\text { Differences }\end{array}$ & $\begin{array}{c}\text { Coefficients } \\
\text { Effect }\end{array}$ & $\begin{array}{c}\text { Coefficient } \\
\%\end{array}$ & $\begin{array}{c}\text { Endowment } \\
\text { Effect }\end{array}$ & $\begin{array}{c}\text { End owment } \\
\%\end{array}$ \\
\hline Han-Hui & 0.0038 & 0.0037 & $97.22 \%$ & 0.0001 & $2.78 \%$ \\
\hline Han-Korean & 0.0076 & 0.0013 & $17.68 \%$ & 0.0063 & $82.32 \%$ \\
\hline Han-Manchu & -0.0011 & -0.0009 & $80.22 \%$ & -0.0002 & $19.78 \%$ \\
\hline Han-Mongolian & 0.0087 & 0.0140 & $161.02 \%$ & -0.0053 & $-61.02 \%$ \\
\hline Han-Uygur & 0.0241 & 0.0253 & $105.01 \%$ & -0.0012 & $-5.01 \%$ \\
\hline Han-Zhuang & 0.0003 & 0.0008 & $264.33 \%$ & -0.0005 & $-164.33 \%$ \\
\hline
\end{tabular}

\begin{tabular}{|l|c|c|c|c|c|}
\hline \multicolumn{1}{|c|}{$\mathbf{2 0 0 0}$} & $\begin{array}{c}\text { LFP Rate } \\
\text { Differences }\end{array}$ & $\begin{array}{c}\text { Coefficients } \\
\text { Effect }\end{array}$ & $\begin{array}{c}\text { Coefficient } \\
\%\end{array}$ & $\begin{array}{c}\text { Endowment } \\
\text { Effect }\end{array}$ & $\begin{array}{c}\text { Endowment } \\
\%\end{array}$ \\
\hline Han-Hui & 0.0186 & 0.0163 & $88.04 \%$ & 0.0022 & $11.96 \%$ \\
\hline Han-Korean & 0.0822 & 0.1122 & $136.37 \%$ & -0.0299 & $-36.37 \%$ \\
\hline Han-Manchu & 0.0002 & -0.0054 & $-2720.87 \%$ & 0.0057 & $2820.87 \%$ \\
\hline Han-Mongolian & 0.0103 & 0.0043 & $41.78 \%$ & 0.0060 & $58.22 \%$ \\
\hline Han-Uygur & 0.0335 & 0.1039 & $310.46 \%$ & -0.0704 & $-210.46 \%$ \\
\hline Han-Zhuang & -0.0091 & -0.0054 & $60.02 \%$ & -0.0036 & $39.98 \%$ \\
\hline
\end{tabular}

Note:

$\begin{array}{ll}1982 & \text { Logit for Mongolian fails chi-squared test } \\ 2000 & \text { Logits for Zhuang and Koreans fail chi-squared tests }\end{array}$

